\title{
Rapid Localization of Bacterial Surface Antigens by Whole-mount Immunoperoxidase Technique
}

\author{
By J. C. COX*, E. PIHL, R. S. D. READ AND R. C. NAIRN \\ Department of Pathology, Monash University, Melbourne, \\ Victoria, Australia
}

(Accepted for publication 9 November 197I)

The immunoperoxidase technique (Nakane \& Pierce, 1966; Avrameas, 1969) has been used in the localization of antigens within cells (e.g. Leduc, Wicker, Avrameas \& Bernhard, 1969), on cell surfaces (Ward, Yamana, Pihl \& Nairn, 1972) and in tissue sections (e.g. Hoedemaeker \& Ito, 1970). The full potential of the technique has not been realized because of some lack of specificity of peroxidase-labelled whole-globulin preparations and the difficulty of preserving antigenicity and morphology in electron-microscopy preparations. This report gives details of a method based upon the coupling of peroxidase to low concentrations of eluted antibody and an immunohistochemical application of the critical-point drying method of preparing biological material for electron microscopy (Anderson, I95I) as modified for the rapid processing of unfixed cells and cell organelles (Pihl \& Bahr, I970).

\section{METHODS}

Peroxidase-labelled antibody. Anti-Brucella abortus serum was prepared in rabbits by giving a single intravenous injection of a saline suspension of $10^{9}$ living organisms of $B$. abortus strain 544 in the smooth form, and bleeding out the animals ro days later (Jones, 1958). A globulin fraction of the antiserum was precipitated with ammonium sulphate at $50 \%$ saturation and the IgG eluted from DEAE cellulose with $0.0175 \mathrm{M}$-phosphate buffer, $\mathrm{pH} 8 \cdot 0$. The IgG was dialysed against phosphate-buffered saline (PBS : $0 \cdot$ I $45 \mathrm{M}-\mathrm{NaCl}, 0 \cdot 0 \mathrm{I} \mathrm{M}-$ sodium phosphate, $\mathrm{pH} 7 \cdot \mathrm{I}$ ) and tested for purity by cellulose acetate electrophoresis and immunoelectrophoresis against anti-whole rabbit serum and antisera specific for rabbit IgG, IgM and IgA (Pentex, Kankakee, Illinois, U.S.A.).

Specific antibody to Brucella abortus was obtained from the IgG by absorption and elution from organisms (Read \& Cox, to be published). Brucella abortus strain 99 (Commonwealth Serum Laboratories, Melbourne, Victoria, Australia) is available as a suspension of organisms, killed by heating at $60^{\circ}$ for $\mathrm{I} h$, for routine agglutination tests. Just sufficient organisms were incubated with the IgG at $37^{\circ}$ for $\mathrm{I} h$ for complete saturation of available antigenic sites by the antibody. The agglutinated organisms were washed twice in PBS, once in $0.15 \mathrm{M}-\mathrm{NaCl}$, and the antibody eluted at $20^{\circ}$ for 30 min with $0^{\circ}$ I M-sodium citrate, $0.1 \mathrm{M}$ sodium phosphate buffer, $\mathrm{pH} 2 \cdot 0$. After centrifugation, the supernatant fraction containing the eluted IgG was dialysed against PBS and concentrated to $0.5 \mathrm{mg} / \mathrm{ml}$ total protein as determined spectrophotometrically at $280 \mathrm{~nm}$ taking $E_{1 \mathrm{~cm}}^{\mathbf{1} \%}=\mathrm{I} 4$.

Horseradish peroxidase (R.Z. = 3. I, Code HPOFF, Worthington Biochemical Co., New Jersey, U.S.A.) was chemically coupled to IgG by means of the bifunctional reagent glutar-

* Present address: Commonwealth Serum Laboratories, Poplar Road, Parkville, Melbourne, Victoria 3052, Australia. 
aldehyde ( $25 \%$ aqueous solution purified for electron microscopy, TAAB Laboratories, Reading, Berkshire) by the method of Avrameas (1969) modified to allow for the tenfold lower protein concentrations available with the eluted antibody. Successful coupling was achieved by dissolving $\mathrm{I} \cdot 2 \mathrm{mg}$ peroxidase in $\mathrm{I} \mathrm{ml}$ of the $\mathrm{IgG}$ solution in PBS to yield approximately a IO: I molecular ratio of peroxidase to IgG. Glutaraldehyde was added slowly to a final concentration of $0.5 \%$ and the mixture allowed to react at $20^{\circ}$ for $2 \mathrm{~h}$.

Immediately after labelling the eluted antibody and a control preparation of normal rabbit IgG made in the same way, each conjugate was passed through a Sephadex G-75 column, of capacity I 6 times the sample volume, and eluted at $4^{\circ}$ with PBS. The sample was observed to separate into two coloured bands, the first containing the conjugate and the second free peroxidase and presumably other products such as peroxidase dimers. The extinction profile at $280 \mathrm{~nm}$ revealed two distinct peaks. The central portion of the first peak was pooled and concentrated to the original sample volume by negative pressure dialysis (Nairn, I969) against $0.05 \mathrm{M}$-tris $\mathrm{HCl}$ buffer, $\mathrm{pH} 7 \cdot 6$, containing $0.105 \mathrm{M}-\mathrm{NaCl}$ and $0.005 \mathrm{M}-\mathrm{MgCl}_{2}$ (TSM buffer). This buffer was used in preference to PBS during all stages of the immunoperoxidase reaction because of superior morphological preservation. The purified conjugate was stored at $-30^{\circ}$. The value for $E_{403 \mathrm{~nm}}: E_{280 \mathrm{~nm}}$, reflecting the ratio of peroxidase to protein, was $2 \cdot 2$ for this conjugate.

Immunoperoxidase reaction, critical-point drying and electron microscopy. One drop of a suspension of Brucella abortus strain 99, washed once in TSM buffer to remove any soluble antigen, was placed on a Formvar-coated, 200-mesh/in grid, allowed to settle for 20 to $30 \mathrm{~s}$, and the non-adherent organisms were washed off with a gentle stream of TSM buffer. Care was taken to avoid drying of the organisms at this and subsequent stages until submitted to the critical-point drying procedure. The conjugate was centrifuged immediately before use at $60,000 \mathrm{~g}_{\mathrm{av}}$ for $20 \mathrm{~min}$ at $10^{\circ}$ to remove any particulate material. A drop was placed on a sheet of wax and the grid, floated face down on this drop, was allowed to react for $15 \mathrm{~min}$ at room temperature in a moist chamber. Control grids were treated in the same way. The use of a wax sheet restricts spreading of the drop, which helps to keep the organisms moist and also permits inverted incubation of the grids; this prevents settling of non-specific reaction products of immunoperoxidase tracing on the preparation. After incubation, the grids were washed in TSM buffer and reacted in a similar fashion for $15 \mathrm{~min}$ with freshly prepared peroxidase substrate, a saturated solution of 3,3'-diaminobenzidine (Graham \& Karnovsky, I966) in TSM buffer containing 0.0I $\% \mathrm{H}_{2} \mathrm{O}_{2}$.

The grids were again washed in TSM buffer, dehydrated at room temperature for $10 \mathrm{~s}$ in aqueous solutions of ethylene glycol of increasing concentrations of 30, 60, 95 and $99 \cdot 5 \%$ (v/v), and impregnated with two changes of ethylene glycol monoethyl ether ('Cellosolve'). At the second change of Cellosolve, the test and control grids were placed in separate compartments around the periphery of a brass washer, which was transferred to a small pressure-chamber. This apparatus, slightly modified from that of Anderson (195I), has a water-jacket, an inlet valve connected to $\mathrm{CO}_{2}$ cylinder, and an exit valve. The inlet valve was opened and the exit valve adjusted to give a flow of liquid $\mathrm{CO}_{2}$ through the chamber for some $30 \mathrm{~min}$ at $15^{\circ}$, completely replacing the Cellosolve. Both valves were closed and the chamber temperature raised to $45^{\circ}$ over 2 or $3 \mathrm{~min}$ by running hot water through the jacket. This is past the critical point of $\mathrm{CO}_{2}\left(72 \cdot 9\right.$ atm at $\left.32 \cdot 5^{\circ}\right)$, at which the liquid becomes gaseous without transition through a gas-liquid equilibrium. Damage to the organisms by surface tension is thereby avoided. After stabilization of the pressure at $45^{\circ}$ (approximately I Io atm) the exit valve was opened and the chamber pressure gradually reduced to atmospheric when the grids were removed and stored over silica gel. 

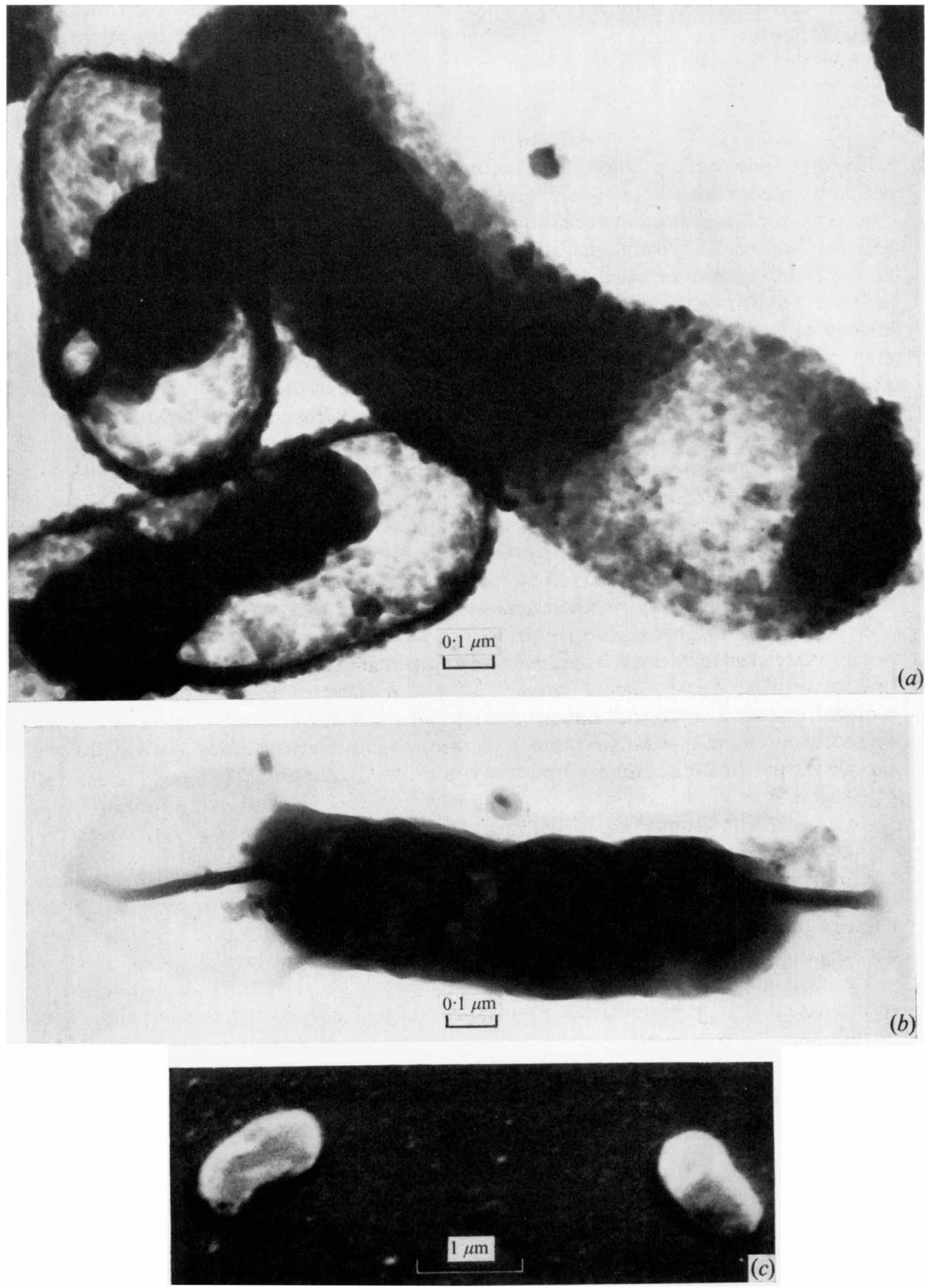

Fig. I (a). Brucella abortus incubated with peroxidase-labelled antibody followed by peroxidase substrate, showing surface deposition of electron-dense reaction product. (b) Brucella abortus incubated with peroxidase-labelled normal rabbit IgG followed by peroxidase substrate showing absence of electron-dense surface deposits. (c) Brucella abortus treated as for Fig. I (b). Stereoscan micrograph showing well-preserved morphology. 
Grids were examined at $100 \mathrm{kV}$ in a Siemens Elmiskop I A and a Philips 300 electron microscope. Stereoscopic pictures were obtained on a Cambridge Stereoscan electron microscope after coating the grids with approximately $30 \mathrm{~nm}$ of gold.

\section{RESULTS}

The morphology of the Brucella abortus organisms was well preserved as judged by examination on the transmission and scanning electron microscope (Fig. I).

Five types of preparation were examined, i.e. organisms treated with peroxidase-labelled anti-Brucella abortus IgG and incubated with peroxidase substrate or TSM buffer containing no substrate, organisms treated with peroxidase-labelled normal rabbit IgG and incubated in peroxidase substrate, organisms incubated only in TSM buffer, and organisms dehydrated directly without incubation. They revealed the expected electron-opaque nucleoplast and an outer zone of lower electron density (Fig. I $a, b$ ). Because the preparations are whole-mounts, not sections, fine structure of the cell wall is not revealed. In preliminary experiments there was little difference seen in morphological preservation between grids dehydrated directly from TSM buffer or after brief aldehyde fixation. Incubation with PBS was detrimental. Living organisms of $B$. abortus strain 99 treated as above were morphologially indistinguishable from those killed by heating at $60^{\circ}$ for $\mathrm{I} h$.

The distribution of the surface-bound antibody revealed by the immunoperoxidase tracing was as fairly regular elevations of the entire bacterial surface by electron-dense masses, about $40 \mathrm{~nm}$ across, with centres some $60 \mathrm{~nm}$ apart (Fig. I $a$ ). This deposition of peroxidase reaction product was observed on all organisms treated with peroxidase-labelled anti-Brucella abortus IgG and incubated with substrate, but was absent from all controls. The positive organisms seemed to be divided approximately equally into two distinct types by the presence or absence of an electron-dense periphery. The significance of this difference is being explored. Resolution on the scanning electron microscope was insufficient to detect the electrondense elevations, although the immunoperoxidase-positive organisms showed a rough surface texture which was absent from the control preparations.

\section{DISCUSSION}

The use of immunochemically purified $\operatorname{IgG}$ as opposed to a labelled whole-globulin fraction was found to diminish non-specific background staining and to increase the contrast between positive and control preparations. Non-specific staining was also reduced by incubating the grids in an inverted position in the peroxidase substrate.

The technique described is a rapid and sensitive method for the ultrastructural localization of surface antigens on bacteria with good preservation of morphology. Possible applications include the investigation of fine morphological and surface antigenic changes associated with attenuation of pathogenic micro-organisms, the detection and localization of cross-reacting or common antigenic sites and the classification of micro-organisms, especially viruses.

The authors thank Dr H. A. Ward, Dr I. G. S. Alexander, Dr B. F. Hoskins and $\mathrm{Mr}$ R. D. Croker for assistance. The work forms part of a M.Sc. thesis by J. C. Cox, who holds a Postgraduate Training Scholarship from the Commonwealth Serum Laboratories and is supported by the National Health and Medical Research Council and the Australian Research Grants Committee. 


\section{REFERENCES}

ANDERSON, T. F. (I95I). Techniques for the preservation of three-dimensional structure in preparing specimens for the electron miscroscope. Transactions of the New York Academy of Science 13, I 30-1 34 .

Avrameas, S. (1969). Coupling of enzymes to proteins with glutaraldehyde - use of the conjugates for the detection of antigens and antibodies. Immunochemistry 6, 43-52.

Graham, R. C. \& KaRnovsKy, M. J. (I966). The early stages of absorption of injected horseradish peroxidase in the proximal tubules of mouse kidney. Ultrastructural cytochemistry by a new technique. Journal of Histochemistry and Cytochemistry 14, 291-302.

HoedemaeKer, P. J. \& ITo, S. (1970). Ultrastructural localization of gastric parietal cell antigen with peroxidase-coupled antibody, Laboratory Investigation 22, I84-I 88.

JONES, L. M. (1958). A recommended method for the preparation of monospecific Brucella sera. World Health Organisation Bulletin 19, I77-I86.

Leduc, E. H., Wicker, R., Avrameas, S. \& Bernhard, W. (I969). Ultrastructural localization of SV 40 T antigen with enzyme labelled antibody. Journal of General Virology 4, 609-6I4.

NaIRN, R. C. (1969). Fluorescent Protein Tracing, 3rd edn. Edinburgh and London: E. and S. Livingstone.

NaKane, P. K. \& Pierce, G. B. (1966). Enzyme-labelled antibodies: Preparation and application for the localization of antigens. Journal of Histochemistry and Cytochemistry 14, 929-93I.

PiHL, E. \& BAHR, G. F. (I970). A new approach to the study of cell organelles with the electron microscope. Experimental Cell Research 59, 379-382.

Ward, H. A., Yamana, S., Pihl, E. \& NaIRN, R. C. (I972). Ultrastructural localization of antilymphocyte globulin on viable lymphocytes by immunoperoxidase tracing. Immunology. (In the press.) 